\title{
COLLECTIVE ACTION FOR GRAZING LAND MANAGEMENT IN CROP- LIVESTOCK MIXED SYSTEMS IN THE HIGHLANDS OF NORTHERN ETHIOPIA
}

\author{
by \\ Berhanu Gebremedhin*, John Pender ${ }^{* *}$ and Girmay Tesfay ${ }^{* * *}$
}

February 2002

Background paper for the CAPRi Workshop on Methods for Studying Collective Action, February 25 - March 1, 2002, in Nyeri, Kenya.

\footnotetext{
${ }_{*}^{*}$ Agricultural Economist, International Livestock Research Institute (ILRI), Addis Ababa

${ }_{* * *}^{* *}$ Senior Research Fellow, International Food Policy Research Institute (IFPRI), Washington D.C.

${ }^{* * *}$ Professor of Agricultural Economics, Mekelle University, Mekelle
} 
We gratefully acknowledge the financial support of the Swiss Agency for Development and Cooperation. We are also grateful to Mekelle University for institutional support and collaboration during the field work and data analysis, the Tigray Regional Bureau Agriculture and Natural Resource Development and the Tigray Regional Bureau of Planning and Economic Development for logistical support and collaboration in the work. We thank Nancy McCarthy of IFPRI for her comments on earlier draft of the manuscript. We are especially thankful to the many farmers and officials who patiently responded to our numerous questions. The usual disclaimer applies. 


\begin{abstract}
Communal grazing lands are important sources of feed in developing countries. The uncontrolled and free grazing system prevalent in many developing countries has caused sever degradation of the grazing lands. Several alternative management options have been recommended to solve the degradation of common property resources, including state ownership, imposition and enforcement of use rules and regulations by external organizations such as the government, private ownership, and community resource management. This paper examines the nature and determinants of collective action for grazing land management in the highlands of Tigray, northern Ethiopia. Results are based on a survey of 100 villages in 1998/99. Indicators of collective action used in the study include area of grazing land under use rules and regulations per household, whether community pays for guard to protect the grazing land, average value of household contributions for grazing land management, whether community established penalty system for violations of use rules and regulations, and whether violations of use rules and regulations occurred. Total number of households per village, involvement of external organizations, distance to nearest market town, if cattle rearing is second most important source of livelihood in village, total number of local organizations in village, heterogeneity in oxen ownership and total area of village were used as determinants of collective action for grazing land management. Analysis of descriptive information, and Tobit and Probit statistical models have been employed. We find that collective action for grazing land management is widespread in the highlands of Tigray and reportedly contribute to sustainable use of the resource. Most collective action is locally initiated and is organized at the village level. We find evidence for an inverted U-shape
\end{abstract}


relationship between population and collective action. Market access detracts from collective action as does wealth heterogeneity of community. Community experience with local organizations favour collective action. These results imply that collective action for grazing land management may be more beneficial and more effective in areas with intermediate population that are far from market places, and with higher social capital. In communities with higher wealth heterogeneity and closer to markets, alternative resource management arrangements such as privatisation may be more effective. 


\section{Introduction}

Communal grazing lands are important sources of livestock feed in developing countries (ILRI, 1998). In the presence of sufficient demand for livestock or livestock products, unrestricted access to the grazing lands may result in overexploitation of the resource and the scarcity rent of the resource would remain unappropriated. Each individual user of the resource enjoys the full benefit of her use of the resource but bears only a fractional part of the cost. As a result, the traditional uncontrolled and free grazing system in many developing countries has caused severe degradation of the grazing lands.

Alternative solutions have been proposed to solve this problem including privatisation, imposition and enforcement of use rules by external forces such as the government, or state ownership of the resource (Wade, 1986). It is unlikely that natural resource problems can be solved by private or state property alone. The transaction cost of enforcing use rules imposed on the community by an external force is likely to be prohibitively high due to the high incentives of individual users to shirk or the community members to collude against the use rules. Privatisation is not always superior to community resource management. For example, McCarthy et al. (2001) argue that private property of communal rangelands will become optimal only when collective action is so poor that it becomes welfare improving to appropriate land individually.

In the presence of collective action, institutional and organisational development, and the development of infrastructure, population pressure is more likely to have a positive impact on natural resources than in the absence of these developments (Pender, 1999). The success of public policies to improve natural resource management depends 
to a large extent on the presence and effectiveness of local level institutions and organisations (Rasmussen and Meinzen-Dick, 1995).

Community natural resource management is increasingly recognised as a viable alternative to privatisation or state ownership of the resource. As a result, local level resource management institutions and organisations to enforce them are receiving greater attention (Baland and Platteau, 1996; Rasmussen and Meinzen-Dick, 1995).

However, devolving rights to local communities to manage resources, establish use rules and regulations, and enforce the rules is only a necessary condition for successful community resource management. Sustainable resource management also requires that community rules and regulations be effectively observed (Swallow and Bromley, 1995; Turner et al., 1994). Hence, identification of the factors that favour or retard the development and effectiveness of local institutions and organisations becomes important.

Although livestock contribute to land degradation, allegations against them are sometimes exaggerated or even unfounded (Ehui et al., 1998). The underlying causes of land degradation may be incomplete property right systems including tenure insecurity, and perverse financial incentives rather than increasing livestock numbers per se. With appropriate livestock development policies and public interventions in technology transfer, livestock have the potential to contribute significantly to the development of sustainable and environment friendly mixed crop-livestock systems. For example, livestock have the potential to speed up the cycling of nutrients in crops back to the soil.

Ethiopia has the largest livestock population in Africa and stands 10th in the world. The livestock sub-sector is an important and integral component of the agricultural 
sector supplying draught power for cultivation, food and income to households, and insurance against risk. However, the contribution of the sub-sector to the country's economy remains far below its potential due to feed, disease and management problems. Communal grazing lands have been important sources of livestock forage in the country. Recently, however, many communal grazing lands have become severely degraded due to the free and uncontrolled grazing system.

The degradation of grazing lands is especially severe in the northern Ethiopian region of Tigray. Cognisant of this problem, the improvement of animal feed production has become one major component in the regional livestock development strategy (Fitsum Hagos et al., 1998). In addition to efforts to increase the number of feed trial and seed multiplication sites, communities have been empowered to develop and enforce use rules and regulations of communal grazing lands. However, there is a paucity of evidence regarding the nature of local level institutions and organisations for grazing land management in Tigray, or their effectiveness. More generally, since community resource management is likely to be context specific, there is a need for more research on community resource management in developing countries. In this regard, Runge (1992, p.34) posits "Much more attention in research needs to be given, however, to the rich variety of contemporary resource management strategies that result from alternative environmental conditions and constraints."

This paper attempts to provide evidence on the determinants of collective action and its effectiveness in communal grazing land management in a low potential highland setting where mixed crop livestock system predominates. The paper has two interrelated objectives. First, using analysis of descriptive information, it evaluates the nature of 
community grazing land management in Tigray. Second, it analyses, using multivariate econometric methods, the factors influencing collective action and its effectiveness in managing grazing lands. Results are based on a survey of 50 communities and 100 villages in the highlands ${ }^{1}$ of Tigray in 1998/999. In this paper, communal grazing lands with use restrictions and regulations are referred to as "restricted grazing lands."

\section{Livestock feeding systems in the highlands of Tigray}

The study area, Tigray, is the northern most region of Ethiopia located on the Sudano-Sahelian dry lands zone. It covers an approximate area of $50,000 \mathrm{~km}^{2}$ with an average population density of about 65 per $\mathrm{km}^{2}$, and population growth rate of about $3 \%$. Most of the area is arid or semiarid with annual precipitation of 450 to $980 \mathrm{~mm}$. Most of the rain falls within the months of June, July and August exhibiting high intensity, and high temporal and spatial variability (Berhanu Gebremedhin, 1998). More than $85 \%$ of the regional population lives in the rural areas and depends on mixed crop-livestock subsistence agriculture.

According to the 1998 livestock census, the region has about 3.04 million cattle, 0.94 million sheep, 1.47 million goats, 0.41 million equines, and 0.013 million camels (BoANRD, 1999). Livestock play an important role in the rural economy of Tigray. They are sources of draught power for traction and transportation, cash income from sale of livestock and livestock products, food such as milk for household consumption and manure to maintain soil fertility. The primary purpose of cattle production in the croplivestock mixed farming systems of the region is draught power.

\footnotetext{
${ }^{1}$ Highlands are defined as those areas which are above 1500 meters above sea level.
} 
The contribution of the livestock sub-sector to the regional economy has been constrained primarily by lack of adequate and quality feed, and livestock diseases. For instance, the annual financial loss due to inadequate feed and management problems was once estimated to reach as high as 46.9 million Birr $^{2}$ for beef production and 230.9 million Birr for milk production (Desta Hagos, 1997).

The major livestock feed sources in the region include crop residues (45\%), grazing lands (35\%), browse (10\%) and crop aftermath (8\%) derived from 3.6 million ha of cultivated land, and 3.2 million ha of grazing land (BOANRD, 1997; UNECA, 1997). Crop residues consist of straw, stalk, stovers, sheath and chaff. About $68 \%$ of the crop residue is fed to oxen, $20 \%$ to milking cows and newly castrated bulls while the remaining balance is fed to other livestock during critical periods (UNECA, 1997). Prickly pear is also increasingly being used as animal feed, mainly in the southern and eastern zones of the region. The spineless cactus is chopped and given to animals while the spiny cactus is treated for spine removal with fire and knives. Considering the total number of livestock and the contributions of different sources of feed, the grazing lands in Tigray are supporting livestock far beyond their carrying capacity (BoANRD, 1997; UNECA, 1997; Gebrekidan Teklu, 1994).

The livestock feed sources in the highlands of Tigray shows slight difference by season (Tsigeweyni Tekleab, 1997). Livestock feed mostly on weeds, and green grass from farm strips and bunds from July to September. From October to December, the dominant feed sources are crop aftermath and range lands. From January to June, crop residues, hay, and cactus in some places are the primary sources of feed. In this altitude

\footnotetext{
${ }^{2}$ In 1998, USD $1=7$ Birr.
} 
zone, the critical feed shortage is observed in the period from July to September, while moderate feed shortage is observed during April to June. The period from October to March is the period of relatively adequate feed.

The grazing system in the region also varies by season. During the rainy season, when most arable lands are under crops, livestock are confined to graze on valley bottoms, farm strips and steep hillsides (Tsigeweyni Tekleab, 1997). The grazing animals cause significant soil disturbance by trampling on the hillsides during the wet season, thus contributing to soil erosion. During the dry season, arable lands become grazing areas.

Free and uncontrolled grazing is the dominant grazing system in the region. In most parts of the region, grazing lands are common property resources ${ }^{3}$. Most of the grazing lands are grazed and trampled the whole year round without any resting period, resulting in depletion of the palatable species and invasion by less palatable or unpalatable ones. Moreover, grazing on crop land contributes to soil compaction and the need for frequent tillage to prepare fields for crops, making practices such as reduced tillage less feasible.

In addition to its contribution to the degradation of grazing lands, the grazing system has a negative effect on the conservation efforts underway in the region. Physical conservation structures such as stone terraces and soil bunds are damaged by the freely roaming livestock. Biological conservation practices such as grass strips and tree plantations are also being destroyed or trampled, reducing the chance for establishment and regeneration.

\footnotetext{
${ }^{3}$ Common property resources are defined as those resources which are collectively owned and managed by a given community. They are to be contrasted with open access resources that have no defined owner.
} 
The free grazing system results in externality costs and benefits to those who do not own livestock. Fallow lands and cultivated lands after harvest are considered as grazing lands without access restrictions. Free grazing reduces vegetative cover thus contributing to soil erosion, reduction of soil fertility, decrease in soil organic matter and deterioration of the soil structure. The farmers who own the land but who own no livestock are forced to bear the cost of maintaining the fertility of the land (for example, by applying commercial fertiliser or manure), or face the consequence of declining yields. However, landowners may also benefit from increased soil fertility due to the manure left by the grazing animals. Whether the externality costs outweigh the benefits remains an empirical question.

Most rural communities in Tigray reserve some grazing areas for dry season feed. In the southern zone, reserved grazing areas are mostly grazed by oxen from February until the onset of the next rainy season, while in the central zone reserved grazing areas are used for hay making or are grazed by the whole livestock herd starting from October. However, the reserved grazing areas appear to be mainly the valley bottoms, thus contributing to the continuous degradation of the hillsides during the rainy season.

In the eastern zone, private ownership of grazing lands is practised, in addition to using reserved grazing areas for hay making. In some woredas (districts) of the zone such as Eurob and Hauzen, the privately held grazing areas are converted to communal grazing lands after about two months of private grazing, while in Saesi Tsaeda Emba, private grazing is practised all year round (Tsigeweyni Tekleab, 1997). In some areas of Saesi Tsaeda Emba, farmers separate reserved grazing lands intended for cows and oxen. While valley bottoms are reserved for oxen, marginal grazing lands are reserved for cows. 
Stall feeding of livestock is not practised in rural Tigray. The shift towards stall feeding needs to be seen within the overall context of agricultural production in the region (Berhanu Gebremedhin, 1998). Stall feeding can increase availability of manure and reduce the energy loss of livestock due to walking in search of feed where there is usually little. On the other hand, stall feeding requires more labour for watering, housing, and breeding. Oxen and pack animals also need the physical exercise required for ploughing and transporting. Stall feeding may, however, be more feasible in more intensive dairy production close to cities.

\section{Conceptual Framework}

The conceptual framework for this study is based on the theory of collective action (Balland and Platteau, 1996; Ostrom, 1990; wade, 1988), institutional analysis (North, 1990) and transaction cost economics (Williamson, 1986). Common property resources can be defined as having two basic characteristics, viz., exclusion is difficult albeit possible, and yield is subtractable (Vanderlinden, 1999). Community members involved in the joint exploitation of a common property resource, therefore, face a dilemma of whether to compete for as big a share from the resource pie as possible or cooperate to increase the resource pie through collective action to manage the resource (Vanderlinden, 1999).

Analysis of individual incentives to contribute to collective action for common property resource management has been the most dominant economic approach to the study of the determinants and effectiveness of collective action (Baland and Platteau, 1999). Underlying these incentives is the perceived distribution of benefits and costs, which may in turn be influenced by factors related to the nature of the resource, the 
characteristics of the community, the interrelationships between the community and the resource, and external environment such as the role of external organizations and programs and access to markets (Agrawal, 2001).

Both institutional analysis (North, 1990) and transactions cost economics (Williamson, 1986) hold that individuals weigh costs and benefits of their decisions in specific action situations. Perceived obstacles and inducements in a given environment condition individual choices (Oakerson, 1992). Hence, in this study factors related to the number of and characteristics of participants involved (by facilitating or hindering trust and cooperation), types of choices available (by raising or decreasing opportunity cost of cooperation), the external environment (through the effect on costs and benefits of the involvement of external organizations or programs), importance of the resource for livelihood, and past experience of community in establishing and running local organizations are considered important in determining collective action for grazing land management..

\section{Research Methods and Hypotheses}

\subsection{Research methods}

The results are based on data collected from a survey of 50 tabias (the lowest administrative unit in Tigray consisting usually of four to five villages) in the highlands of Tigray in the 1998-99 cropping year. Sample tabias were selected using a stratified random sampling. Tabias were stratified based on distance from the nearest market town and presence of an irrigation project. Two villages were selected randomly from each tabia. A semi-structured questionnaire was administered in a group interview with community representatives at both the tabia and village levels. Each interview involved 
ten respondents chosen to represent different age groups, villages, primary occupations and gender. The survey collected information about changes in agricultural and natural resource conditions between 1991 and 1998, and their causes and effects.

Descriptive analysis of survey data was used to identify the nature and impact of community management on grazing lands, the role of local and external organisations in managing them, the institutions that evolved and their enforcement mechanisms. Econometric analysis was used to examine the determinants of collective action and its effectiveness in managing grazing lands.

Effective collective action for resource management requires that the beneficiaries prepare and agree on a set of rules of restrained access to the resource; make arrangements for financial, labor or other contributions required for the management of the resource; and lay out a system of enforcement of the use restrictions and community contributions. Thus, the indicators of collective action and its effectiveness used in the econometric analysis include (1) area of restricted grazing land per household (2) whether communities pay for guard to protect the grazing land (3) the monetary value of contribution per household for grazing land management (4) whether communities established penalty systems for violations of use restrictions and (5) whether violations of use rules and regulations occurred in 1998. Communal grazing lands are used in every village, and the total area of the communal grazing land under use restrictions (restricted grazing area) is considered as an indicator of collective action. Community members may respond to non-cooperation by cooperating to increase each other's incentive to cooperate, through exhortation and penalties. Thus, establishment of penalty system is 
used as an indicator of collective action. Violations of use restrictions and regulations is used as an indicator of failure of collective action.

The type of regression model to use depends on the nature of the dependent variable. We use binary probit models to examine the determinants of whether communities pay for guard, whether penalties were established, and whether any violations occurred in 1998. We use a Tobit model for area of restricted grazing land per household and contributions per household for grazing land management since the data are censored. We corrected for sampling stratification and weights using the survey data estimation version for probit models (SVYPROBT), and the Tobit model (SVYINTRG) using STATA software.

\subsection{Hypotheses}

The factors used to explain differences in collective action include the number of total households in a village, heterogeneity in oxen ownership of the community, experience with local organizations, distance to market, involvement of external organizations or programs, whether cattle production is the second most important source of livelihood in a community, and the total area of the community.

When the number of households is small, collective action may be low due to fixed costs, while when number of households is very high collective action may be low due to increasing variable transaction costs of attaining and enforcing collective action, or higher competition for the resource (Pender and Scherr, 1999; Berhanu Gebremedhin et al. 2001; Otsuka and Place, 2001). Hence we hypothesize an inverted U-shape relationship between number of households in a village and collective action for grazing 
land management with intermediate levels of population density favouring collective action, while low and very high population densities retarding collective action.

The effect of heterogeneity on collective action is unresolved since communities may be heterogeneous in several aspects including socio-cultural background, interests and endowments, and each of these aspects may affect collective action differently (Baland and Platteau, 1999; Baland and Platteau, 1996). The conditions under which certain aspects of heterogeneity enhance or undermine collective action also remains unknown (Varughese and Ostrom, 2001). In this study, we considered heterogeneity in terms of oxen ownership in the community. We hypothesize that heterogeneity in oxen ownership may undermine collective action for grazing land management because of possible divergence of interests in and perceived benefits from use of the grazing lands. Since land in the study area is equitably distributed based on family size, oxen ownership remains an important differentiation factor of economic classes. We measured heterogeneity by the coefficient of variation of the distribution of the proportion of households with no oxen, one ox, two oxen, and more than two oxen.

External organisations can favour collective action by providing technical support and inputs, provided that these interventions are complementary to local collective action and demand driven. On the other hand, external organisations may retard collective action if their role substitutes for local collective action (such as by replacing local effort or dictating management decisions) or otherwise undermining collective action (such as by increasing "exit options" of local community members) (Berhanu Gebremedhin et al., 2001; Pender and Scherr, 1999). We investigated the effect of external organizations by including a dummy variable for whether the restricted grazing area was promoted by an 
external organization. Since almost all restricted grazing areas are managed at the village level, we are not able to test for the effect of the level of management (i.e., village vs. tabia) on collective action.

Experience with local organizations should favour collective action due to possible learning effects, and the effect of social capital on the costs or ability to enforce collective action (Baland and Platteau, 1996; Pender and Scherr, 1999; Rasmussen and Meinzen-Dick, 1995). Up to ten different local organizations operate in the study area. Not all communities have all the local organizations. We measured differences in community experience with local organizations by the number of local organizations operating in a given community.

Communities who depend on a common property resource and are likely to use the resource over a long time horizon may be more likely to self-organize to manage the resource collectively (Varughese and Ostrom, 2001). The primary source of livelihood for rural communities in the study area is cereal crops production. Communities showed difference in their second most important source of livelihood. We include a dummy variable of whether the second most important livelihood source in a given community is cattle rearing. We expect that where cattle rearing is important livelihood strategy, collective action for grazing land management will be high.

The effect of market access on collective action is mixed. While better market access may increase the value of the resource and the return from managing the resource effectively, thus favouring collective action, better market access may also decrease the incentive of members to abide by community rules by increasing the opportunity cost of labor or by providing more "exit" options, making enforcement of rules more difficult 
(Berhanu Gebremedhin, et al., 2001; Pender and Scherr, 1999; Baland and Platteau, 1996). We measured market access by the walking time to the nearest market town from the village.

\section{Results}

\subsection{Descriptive Analysis}

Grazing areas with some regulations of use (restricted grazing areas) are common in rural communities in the highlands of Tigray. All villages in the highlands have some type of grazing land (including both unrestricted and restricted grazing areas), and almost $90 \%$ of villages have one or more restricted grazing areas. The average total restricted grazing land area per village is 38 ha and the average area of a particular grazing land is 10.5 ha (Table 1). On average, each village in the highlands has about four restricted grazing areas. However, there is a wide variation in the number and area of restricted grazing lands per village.

Almost all restricted grazing areas are used exclusively by the village that manages them. More than half of the restricted grazing areas are used for grazing only by oxen while the remaining are grazed by all animals. There is a variation in the period during which the grazing lands are used for grazing. In $42 \%$ of the cases the grazing lands are used only from September to December, 29\% from January to May, and 13\% from June to August. Only oxen are allowed to graze in the rainy season from June to August. In a few cases, grazing is allowed after the grass is cut.

In addition to grazing livestock, other allowed uses of the restricted grazing areas include cutting grass for feed or construction, fuel wood collection from dead trees, dung 
collection, and bee keeping. However, cutting trees or shrubs is not allowed. All communities reported that the grazing lands have regenerated significantly due to the restricted uses.

There appears to be a long tradition of developing and enforcing use regulations of grazing areas in Tigray. More than 58\% of the restricted grazing areas in the surveyed villages were established prior to 1966 , while only about $17 \%$ percent have been established since 1991. On average a restricted grazing area in the highlands was established 23 years ago. The village administration is the local organisation principally mandated for the management of the grazing areas. In a few cases, a group of elders has the management responsibility. In addition to the village organisations, the regional Bureau of Agriculture is also involved in management of the grazing areas. The village administration is mostly involved in organizing potential beneficiaries, drafting of use rules and regulations, and enforcement of the rules once they are ratified by beneficiaries. In a few cases the village administration finances guards. The Bureau of Agriculture is mainly involved in the provision of material and technical assistance, with limited role in organizing beneficiaries. The Bureau is not involved in the preparation of use rules and regulations.

The most frequent contribution of village members in management of the grazing lands is cash or in kind contribution for guard payment. Other contributions of village residents include uncompensated labor contribution for the construction of soil and water conservation practices, guarding the area on rotation basis, and fencing and weeding. The average Birr value of total community contributions for management of a grazing land in 1998 was 1, 580 (US\$226) per grazing land, with per ha average value of Birr 300 (US\$ 43). The average contribution per household was Birr 3.66. 
Table 1. Characteristics and Allowed Uses of Restricted Grazing Areas (standard errors in parentheses)*

\begin{tabular}{|c|c|c|}
\hline Item & $\begin{array}{l}\text { Village } \\
\text { level }\end{array}$ & $\begin{array}{l}\text { Grazing } \\
\text { area } \\
\text { Level }\end{array}$ \\
\hline Percentage of villages with restricted grazing lands & $\begin{array}{l}89 \\
(0.0096)\end{array}$ & \\
\hline Number of restricted grazing lands per village & $\begin{array}{l}3.98 \\
(0.165)\end{array}$ & \\
\hline Average area of restricted grazing lands (ha) & $\begin{array}{l}38.2 \\
(3.615)\end{array}$ & $\begin{array}{l}10.45 \\
(1.112)\end{array}$ \\
\hline Average age of restricted grazing land & & $\begin{array}{l}23 \\
(0.814)\end{array}$ \\
\hline $\begin{array}{l}\text { Percentage of grazing lands promoted by external } \\
\text { organisations }\end{array}$ & & $\begin{array}{l}32 \\
(0.0349)\end{array}$ \\
\hline \multicolumn{3}{|l|}{$\begin{array}{l}\text { Value of community contribution for grazing land } \\
\text { management (Birr): }\end{array}$} \\
\hline Value per grazing land & & $\begin{array}{l}1580 \\
(615.28)\end{array}$ \\
\hline Value per hectare & & $\begin{array}{l}300 \\
(60.48)\end{array}$ \\
\hline Value per household & & $\begin{array}{l}3.66 \\
(0.852)\end{array}$ \\
\hline \multicolumn{3}{|l|}{ Allowed uses of restricted grazing lands (percent) } \\
\hline cutting grass & & $\begin{array}{l}22 \\
(0.03)\end{array}$ \\
\hline fuelwood collection & & $\begin{array}{l}53 \\
(0.034)\end{array}$ \\
\hline collecting dung & & $\begin{array}{l}90 \\
(0.021)\end{array}$ \\
\hline collecting fruits & & $\begin{array}{l}66 \\
(0.033)\end{array}$ \\
\hline beekeeping & & $\begin{array}{l}60 \\
(0.032)\end{array}$ \\
\hline cutting trees & & $\begin{array}{l}0 \\
(0.0)\end{array}$ \\
\hline
\end{tabular}

* Means and standard errors are corrected for sampling stratification and weights. 
Most grazing areas in the highlands $(68 \%)$ were not promoted by an external organisation or program, indicating the prevalence of local initiative for collective action in managing grazing lands. In cases where the grazing areas were promoted by an organisation or a program, the Bureau of Agriculture took the lead.

The most common way of protecting the grazing lands is by hiring guards $(77 \%$ of restricted grazing areas) paid by contributions from households in cash or in kind, or in return for benefits from using the grazing areas. The dominant way of compensating guards is payment in cash or in kind. In a few cases guards are paid from food-for-work programs. When cash payment is used, a guard is paid 40 Birr/month (US \$6.00) on average. In some villages only those who own oxen contribute for guard payment. When a guard is not hired, village households rotate the responsibility for guarding the grazing lands ( $21.5 \%$ of restricted grazing areas) or fence the grazing land $(0.8 \%$ of restricted grazing areas). Mutual trust among villagers is used in $0.4 \%$ of the cases.

Penalties for violations of use restrictions of grazing lands are widely used in the highlands of Tigray. In 1998, violations of use restrictions were reported in $26 \%$ of the restricted grazing lands. In about $81 \%$ of the cases, violations were penalized when they occurred. Farmers do not perceive any problems as a result of the use restrictions of the grazing areas in terms of shortage of grass, harbouring pests, fire hazard, shortage of fuel wood, or uncertainty about receiving benefit from them. All restricted areas remained restricted once they were established.

The most frequent violations of use restrictions of the grazing lands reported in 1998 were letting animals graze while grazing was not allowed, and cutting grass for feed and construction without permission. Other violations include cutting roots, branches, 
leaves or trees, and collecting fuel wood. Communities mostly use penalty in cash for violations.

The survey asked about penalties used by communities for violations of use restrictions when the area was first established and in 1998. Among the violations that were penalized by cash fine, $61 \%$ of cash penalties during establishment and $72 \%$ of cash penalties in 1998 were applied to violations of grazing animals and cutting grass and trees. In some cases ( $21 \%$ of penalties during establishment and $18 \%$ in 1998) the village courts were mandated to decide on penalties for violations. Confiscation of the cut grass and trees, and implements were used in few cases.

Compared to during establishment the frequency of use of cash penalties and imprisonment increased by 1998, while mandating the village court to decide on penalties, penalty in kind and confiscation decreased in 1998. In a few cases penalties were not initially developed when the use restrictions were first established.

The most frequently cited benefit received from the grazing lands in 1998 is grazing animals while feed is in short supply. On average, $42 \%$ of households in each village received benefit from grazing animals in 1998. Other benefits to rural households include cutting grass for feed and other purposes, collecting dung, and collecting fuel wood from dead trees.

Some indicators of collective action showed significant differences by market $\operatorname{access}^{4}$ (Table2). Villages with relatively lower market access reported significantly higher violations of use rules and regulations but made significantly higher contributions

\footnotetext{
${ }^{4}$ Communities were classified into high market access if the distance to the nearest market place is less than or equal to $10 \mathrm{~km}$, while of low market access if the distance is more than $10 \mathrm{~km}$.
} 
per household for grazing land management. There was no significant difference in the other indicators of collective action based on market access.

Table 2: $\quad$ Indicators of Collective Action for Grazing Land Management by Market Access $^{\ddagger \dagger}$ (standard error)

\begin{tabular}{|c|c|c|}
\hline Indicator & $\begin{array}{l}\text { Low market } \\
\text { access }\end{array}$ & $\begin{array}{l}\text { High market } \\
\text { Access }\end{array}$ \\
\hline Percentage of villages with restricted grazing area & $\begin{array}{l}75.62 \mathrm{a} \\
(0.059)\end{array}$ & $\begin{array}{l}63.65 \mathrm{a} \\
(0.089)\end{array}$ \\
\hline Average restricted area per household (ha) & $\begin{array}{l}0.349 \mathrm{a} \\
(0.064)\end{array}$ & $\begin{array}{l}0.403 \mathrm{a} \\
(0.157)\end{array}$ \\
\hline $\begin{array}{l}\text { If community pays for guard (percent of restricted } \\
\text { grazing areas) }\end{array}$ & $\begin{array}{l}74.49 \mathrm{a} \\
(0.050)\end{array}$ & $\begin{array}{l}67.21 \mathrm{a} \\
(0.069)\end{array}$ \\
\hline $\begin{array}{l}\text { If community established penalty system (percent } \\
\text { of restricted grazing areas) }\end{array}$ & $\begin{array}{l}98.21 \mathrm{a} \\
(0.009)\end{array}$ & $\begin{array}{l}95.30 \mathrm{a} \\
(0.023)\end{array}$ \\
\hline $\begin{array}{l}\text { If violations of use restrictions occurred (percent of } \\
\text { restricted grazing areas) }\end{array}$ & $\begin{array}{l}43.10 \mathrm{a} \\
(0.044)\end{array}$ & $\begin{array}{l}5.20 \mathrm{~b} \\
(0.021)\end{array}$ \\
\hline $\begin{array}{l}\text { Average per household contributions for restricted } \\
\text { grazing land management (Birr) }\end{array}$ & $\begin{array}{l}4.239 \mathrm{a} \\
(1.081)\end{array}$ & $\begin{array}{l}1.573 b \\
(0.414)\end{array}$ \\
\hline $\begin{array}{l}\text { Average per hectare value of community } \\
\text { contribution for restricted grazing land } \\
\text { management in } 1998 \text { (Birr) }\end{array}$ & $\begin{array}{l}192.30 \mathrm{a} \\
(53.23)\end{array}$ & $\begin{array}{l}326.31 \mathrm{a} \\
(74.89)\end{array}$ \\
\hline
\end{tabular}

When communities are classified in to high and low population densities ${ }^{5}$, most of the indicators of collective action were significantly different (Table 3). Average area of restricted grazing land per household, percentage of villages which 
established penalty system, percentage of violations of uyse rules and regulation in 1998, and average household contribution for grazing land management were higher at low population density, while the percentage of communities paying for guard was higher at higher population density.

Table 3: $\quad$ Indicators of Collective Action for Grazing Land Management by Population Density in Community ${ }^{\dagger \dagger}$ (standard error)

\begin{tabular}{|c|c|c|}
\hline Indicator & $\begin{array}{l}\text { Low } \\
\text { population } \\
\text { density }\end{array}$ & $\begin{array}{l}\text { High } \\
\text { population } \\
\text { density }\end{array}$ \\
\hline Percentage of villages with restricted grazing area & $\begin{array}{l}80.08 \mathrm{a} \\
(0.083)\end{array}$ & $\begin{array}{l}73.32 \mathrm{a} \\
(0.0612)\end{array}$ \\
\hline Average restricted area per household (ha) & $\begin{array}{l}0.133 a \\
(0.041)\end{array}$ & $\begin{array}{l}0.040 b \\
(0.010)\end{array}$ \\
\hline $\begin{array}{l}\text { If community pays for guard (percent of restricted } \\
\text { grazing land) }\end{array}$ & $\begin{array}{l}60.58 \mathrm{a} \\
(0.087)\end{array}$ & $\begin{array}{l}78.26 b \\
(0.043)\end{array}$ \\
\hline $\begin{array}{l}\text { If community established penalty system (percent of } \\
\text { restricted grazing area) }\end{array}$ & $\begin{array}{l}99.27 \mathrm{a} \\
(0.007)\end{array}$ & $\begin{array}{l}96.77 b \\
(0.012)\end{array}$ \\
\hline $\begin{array}{l}\text { If violations of use restrictions occurred (percent of } \\
\text { restricted grazing land) }\end{array}$ & $\begin{array}{l}40.24 \mathrm{a} \\
(0.067)\end{array}$ & $\begin{array}{l}32.78 b \\
(0.042)\end{array}$ \\
\hline $\begin{array}{l}\text { Average per household contribution for restricted } \\
\text { grazing land management (Birr) }\end{array}$ & $\begin{array}{l}7.694 a \\
(2.331)\end{array}$ & $\begin{array}{l}1.569 b \\
(0.306)\end{array}$ \\
\hline $\begin{array}{l}\text { Average per hectare value of community } \\
\text { contribution for restricted grazing land management } \\
\text { in } 1998 \text { (Birr) }\end{array}$ & $\begin{array}{l}281.80 \mathrm{a} \\
(86.10)\end{array}$ & $\begin{array}{l}305.28 \mathrm{a} \\
(78.91)\end{array}$ \\
\hline
\end{tabular}

\footnotetext{
${ }^{5}$ Communities were classified as low population density areas if population density is less than or equal to 100 per $\mathrm{km}^{2}$ and high population density if higher than 100 per $\mathrm{km}^{2}$.
} 
Some indicators of collective action also showed marked difference across zones ${ }^{6}$, perhaps due to differences in agro-climatic potential and other zonal specific factors

(Table 4). The southern zone has the highest percentage of villages with restricted

Table 4: Indicators of Collective Action for Grazing Land Management by Zone $^{\dagger \ddagger}$ (standard error)

\begin{tabular}{lllll}
\hline Indicator & $\begin{array}{l}\text { Southern } \\
\text { Zone }\end{array}$ & $\begin{array}{l}\text { Central } \\
\text { Zone }\end{array}$ & $\begin{array}{l}\text { Eastern } \\
\text { Zone }\end{array}$ & $\begin{array}{l}\text { Western } \\
\text { Zone }\end{array}$ \\
\hline $\begin{array}{l}\text { Percentage of villages with restricted } \\
\text { grazing area }\end{array}$ & $\begin{array}{l}93.75 \mathrm{a} \\
(0.051)\end{array}$ & $\begin{array}{l}60.72 \mathrm{~b} \\
(0.968)\end{array}$ & $\begin{array}{l}75.23 \mathrm{ab} \\
(0.103)\end{array}$ & $\begin{array}{l}54.02 \mathrm{bc} \\
(0.151)\end{array}$ \\
& & & & \\
& & & & \\
Average restricted area per household & $0.162 \mathrm{a}$ & $0.023 \mathrm{bc}$ & $0.042 \mathrm{c}$ & $0.009 \mathrm{~d}$ \\
(ha) & $(0.045)$ & $(0.008)$ & $(0.011)$ & $(0.003)$ \\
$\begin{array}{l}\text { If community pays for guard (percent of } \\
\text { restricted grazing land) }\end{array}$ & $\begin{array}{l}50.49 \mathrm{a} \\
(0.076)\end{array}$ & $\begin{array}{l}85.02 \mathrm{bc} \\
(0.054)\end{array}$ & $\begin{array}{l}82.80 \mathrm{c} \\
(0.053)\end{array}$ & $\begin{array}{c}100 \mathrm{~d} \\
(0.0)\end{array}$ \\
$\begin{array}{l}\text { If community established penalty system } \\
\text { (percent of restricted grazing area) }\end{array}$ & $\begin{array}{l}97.18 \mathrm{a} \\
(0.016)\end{array}$ & $\begin{array}{l}99.28 \mathrm{a} \\
(0.007)\end{array}$ & $\begin{array}{l}97.59 \mathrm{a} \\
(0.013)\end{array}$ & $\begin{array}{l}94.19 \mathrm{a} \\
(0.058)\end{array}$ \\
$\begin{array}{l}\text { If violations of use restrictions occurred } \\
\text { (percent of restricted grazing land) }\end{array}$ & $\begin{array}{l}53.22 \mathrm{a} \\
(0.057)\end{array}$ & $\begin{array}{l}32.61 \mathrm{~b} \\
(0.081)\end{array}$ & $\begin{array}{l}7.54 \mathrm{c} \\
(0.037)\end{array}$ & $\begin{array}{l}58.04 \mathrm{ab} \\
(0.178)\end{array}$ \\
$\begin{array}{l}\text { Average per household contribution for } \\
\text { grazing land management (Birr) }\end{array}$ & $\begin{array}{l}4.637 \mathrm{a} \\
(1.418)\end{array}$ & $\begin{array}{l}4.104 \mathrm{a} \\
(1.567)\end{array}$ & $\begin{array}{l}0.544 \mathrm{~b} \\
(0.159)\end{array}$ & $\begin{array}{l}11.74 \mathrm{ab} \\
(8.977)\end{array}$ \\
$\begin{array}{l}\text { Average per hectare value of community } \\
\text { contribution for restricted grazing land } \\
\text { management in 1998 (Birr) }\end{array}$ & $\begin{array}{l}217.44 \mathrm{a} \\
(45.74)\end{array}$ & $\begin{array}{l}657.83 \mathrm{~b} \\
(223.63)\end{array}$ & $\begin{array}{l}100.02 \mathrm{c} \\
(32.15)\end{array}$ & $\begin{array}{l}707.52 \mathrm{abc} \\
(506.49)\end{array}$ \\
\hline
\end{tabular}

$\dagger \overline{\text { Figures (in the same row) followed by different letters are significantly different from each other at least }}$ at the $10 \%$ level.

†Means were corrected for sampling stratification and weights, and standard errors are robust to hetroskedasticity and non-independence within the primary sampling units (tabias).

grazing lands, and the largest area of restricted grazing land per household while the western and central zones have the smallest areas of restricted grazing land per household. Villages in the western zone are most likely to pay for guard, followed by the central and eastern zones. The eastern zone had the fewest percentage of violations of use

\footnotetext{
${ }^{6}$ The Tigray Region is divided into four rural zones (Southern, Central, Eastern and Western). The Southern and Western zones are relatively high potential zones, and the western zone has relatively
} 
restrictions and regulations in 1998, and the lowest value of per household and per hectare contributions for grazing land management. The econometric analysis shows whether the differences in collective action by market access, population and zones are significant after controlling for other variables.

To summarize the descriptive analysis, we find that restricted grazing areas are widespread in the highlands of Tigray, and are managed only at the village level. Most grazing areas are established through local initiative, and village administrations are principally involved in management. Village members contribute cash or in kind for guard payment, and contribute uncompensated labour for management. When a guard is not used for protection, village members take turns to protect the land or use fences. The regional Bureau of Agriculture is involved mainly in the provision of technical and material assistance. Since oxen supply draught power for traction, a critical input for crop production, the restricted lands are mainly used for grazing oxen. Communities use cash penalties for violations. The level and effectiveness of collective action for grazing land management appears to differ by population density and market access, as well as across zones. In the next section, we present results of econometric analysis on the determinants of collective action and its effectiveness.

\subsection{Econometric Analysis}

The results of econometric analysis are given presented in Table 3. We include dummy variables for the different zones of Tigray to proxy for differences in agroclimatic potential (the Southern and Western zones have generally higher potential, due to better soils and higher rainfall), as well as other zone specific differences. We include 
population density and population density squared to test for an inverted U-shape relationship between population density and collective action

We find that the Western zone has the least area of restricted grazing lands per household, consistent with the existence of a relatively more abundant grazing land in the zone compared to other zones of the region, thus perhaps reducing the need for restricted grazing areas. The Central and Eastern zones also have less area of restricted grazing lands per household compared with the Southern zone. We also find that communities in the Central zone are more likely to pay for guard and are more likely to establish penalty systems for violations of use restrictions and regulations than in the Southern zone. Communities in the Eastern zone are less likely to violate use rules and restrictions and more likely to establish penalty systems than in the Southern zone.

Communities are more likely to pay for guard at intermediate population than at low or very high total population. The turning point in this relationship (where maximum probability of communities paying for guard occurs) is 450 households per village, well within the range of total number of households per village and very close to the average number of households per village (total number of households per village in the study area ranged from 85 to 1050 with an average value of 410). We also find violations of use restrictions are least likely to occur at intermediate population (368 households per village). These results of the effect of population on collective action for grazing land management are consistent with the hypothesis of an inverted U-shape relationship between population and collective action. Collective action is probably low at low population due to the effect of fixed costs associated with collective action and at very 
high population due to the increasing marginal costs of collective action as population increases.

The involvement of external organizations in promoting restricted grazing areas reduced the likelihood of communities paying for guard, suggesting that the need for communities to pay for guard is eliminated by the payment made by the external organizations. Involvement of external organizations has a positive (but statistically insignificant) effect on household contributions for grazing land management.

Communities with greater presence of local organizations make higher contributions per household for grazing land management, are more likely to establish a penalty system and are less likely to have violations of use restrictions and regulations. These results are consistent with the hypothesised effect of experience with local organizations on collective action for resource management. However, we also find a negative effect of experience with local organizations on the likelihood of communities paying for a guard; similar to the effect of involvement of external organizations. Perhaps a guard is less necessary in communities with greater investment in such local social capital.

Communities that are more distant from the nearest market town are more likely to pay for guard and to establish a penalty system for grazing land management, suggesting that more distant communities have higher need for restricted grazing lands, and that collective action may be more likely because of lower opportunity cost of labour or limited exit options in such areas. These results suggest that in areas closer to markets, private management of grazing lands may be a better option. 
Whether or not cattle rearing is a second most important source of livelihood in a community failed to affect any of the indicators of collective action significantly. This may be because of the fact that cereal crops production is the first most important source of livelihood in all communities and cattle rearing is considered as supplementary to crop production.

Heterogeneity in oxen ownership tends to detract from collective action for grazing land management. Heterogeneity increases the likelihood of violations of use restrictions and regulations (an indicator of failure of collective action). Heterogeneity explained household contribution for grazing land management negatively but was statistically insignificant. We also find that total area of community has a positive effect on area of restricted grazing land per household.

A possible explanation for the weak influence of some of the explanatory variables is that there may be multicollinearity among the explanatory variables. We tested for problems of multicollinearity and found that potential problems only between the total number of households in village and its squared value. We have retained both variables as they were necessary to test the hypothesized inverted U-shaped relationship. The variance inflation factors of all other variables were below 3 


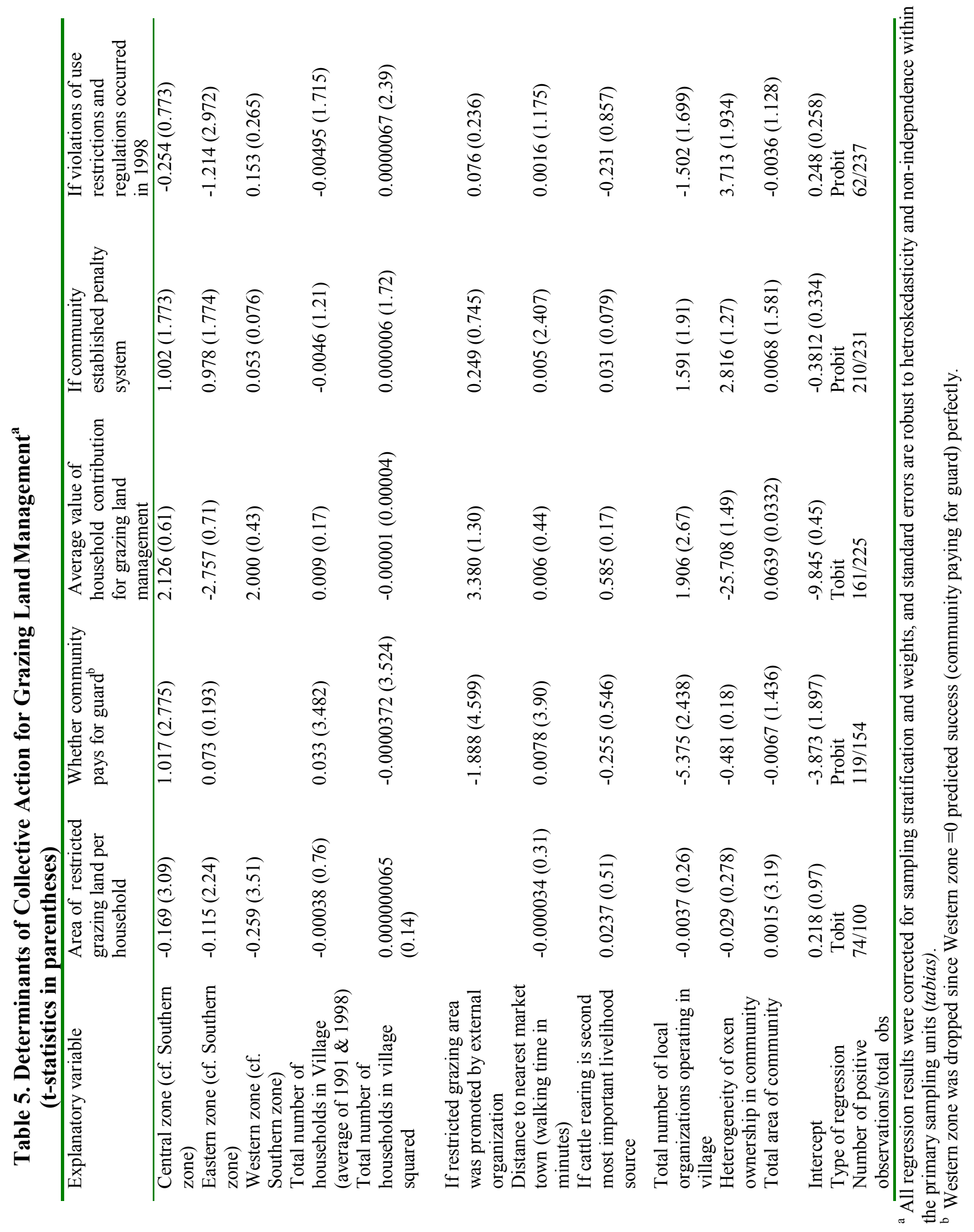




\section{Conclusions and Implications}

Rural communities in Tigray have long tradition of developing and enforcing use regulations of grazing areas. According to survey respondents, use regulations reportedly contribute to significant regeneration of grazing lands, supporting the role of community resource management in redressing resource degradation. Restricted use of grazing lands are maintained once established. Village organisations are primarily responsible for the management of restricted grazing areas by organising and informing beneficiaries, and establishing and enforcing use regulations; with technical and material assistance from the regional Bureau of Agriculture. Beneficiaries contribute to grazing land management through cash and in kind contributions for protection and uncompensated labour contribution for the development of the grazing lands. Given the crucial role of traction for crop production, oxen are the priority users of the restricted grazing lands.

Communities which have smaller areas of restricted grazing lands per household exhibited higher levels of various indicators of collective action for grazing land management, such as communities paying for guard, establishment of penalty systems and reporting less violations. These results, combined with the finding that restricted grazing areas remain enforced once established, suggest that once the hurdle of establishment of restricted grazing areas is overcome, collective action is likely to be effective.

We found evidence for an inverted U-shape relationship between population level and collective action for grazing land management. Collective action is highest at intermediate population level. When population is low the fixed costs of collective action per head is high, thus 
undermining cooperation. At high population level, the increasing variable costs of collective action detract cooperative efforts.

Experience in organizing and running local organizations encourages collective actions for grazing land management, perhaps due to the learning effect of managing cooperative effort, or because social capital helps to reduce the cost of attaining and enforcing collective action. Market access may detract from collective action by increasing the opportunity cost of labour or by providing more exit options to rural communities. Heterogeneity in oxen ownership appears to detract from collective action for grazing land management.

The findings imply that community grazing land management can contribute to a more sustainable use of grazing lands and the alleviation of feed shortage problems. Collective action for grazing land management may be more beneficial and more effective in areas with intermediate population, that are far from market places. In communities with higher wealth heterogeneity and closer to markets, alternative resource management arrangements such as privatization may be more effective. 


\section{Annex: Summary Statistics of Variables Used in Regressions*}

\begin{tabular}{|c|c|c|c|c|c|}
\hline Variable & $\begin{array}{l}\text { No. of } \\
\text { Observations }\end{array}$ & Mean & $\begin{array}{l}\text { Standard } \\
\text { error }\end{array}$ & Minimum & Maximum \\
\hline $\begin{array}{l}\text { Whether village has } \\
\text { restricted grazing area }\end{array}$ & 100 & 0.89 & 0.050 & 0 & 1 \\
\hline $\begin{array}{l}\text { Area of restricted grazing } \\
\text { area per household (ha) }\end{array}$ & 100 & 0.067 & 0.015 & 0 & 1.916 \\
\hline $\begin{array}{l}\text { Whether community pays } \\
\text { for guard }\end{array}$ & 154 & .72 & 0.042 & 0 & 1 \\
\hline $\begin{array}{l}\text { Average household } \\
\text { contribution for grazing } \\
\text { land management (Birr) }\end{array}$ & 226 & 3.661 & 0.852 & 0 & 63.157 \\
\hline $\begin{array}{l}\text { Whether village established } \\
\text { penalties }\end{array}$ & 231 & 0.97 & 0.008 & 0 & 1 \\
\hline Whether violations occurred & 229 & 0.35 & 0.036 & 0 & 1 \\
\hline Eastern zone & 231 & 0.23 & 0.047 & 0 & 1 \\
\hline Southern zone & 231 & 0.30 & 0.050 & 0 & 1 \\
\hline Western zone & 231 & 0.13 & 0.038 & 0 & 1 \\
\hline Central zone & 231 & 0.32 & 0.053 & 0 & 1 \\
\hline Households per village & 100 & 410 & 20.62 & 85 & 1050 \\
\hline $\begin{array}{l}\text { Walking distance from } \\
\text { village to nearest woreda } \\
\text { town (minutes) } \\
\text { If grazing land promoted }\end{array}$ & 231 & 200 & 8.04 & 10 & 720 \\
\hline $\begin{array}{l}\text { by external organisation } \\
\text { If cattle rearing is second }\end{array}$ & 231 & 0.31 & 0.035 & 0 & 1 \\
\hline $\begin{array}{l}\text { most important livelihood } \\
\text { source }\end{array}$ & 231 & 0.68 & 0.053 & 0 & 1 \\
\hline $\begin{array}{l}\text { Number of local } \\
\text { organizations operating in } \\
\text { village }\end{array}$ & 231 & 4.1 & 0.124 & 1 & 6 \\
\hline $\begin{array}{l}\text { Heterogeneity of oxen } \\
\text { ownership (coefficient of } \\
\text { variation) }\end{array}$ & 231 & 0.25 & 0.007 & 0.10 & 0.45 \\
\hline Area of community $\left(\mathrm{km}^{2}\right)$ & 231 & 62.08 & 4.78 & 12.3 & 179 \\
\hline
\end{tabular}

* Means and standard errors are corrected for sampling weights and stratification. 


\section{References}

Agrawal, A. 2001. Common Property Institutions and Sustainable Governance of Resources. World development, 29(10):1649-1672.

Baland J-M and Platteau, J-P. 1999. The Ambiguous Impact of Inequality on Local Resource Management. World development, 27(5): 773-788.

Baland, J-M and Platteau, J-P. 1996. Halting Degradation of Natural Resources: Is there a role forRrural Communities? Oxford University Press, Oxford, UK. 423 pp.

Berhanu Gebremedhin, Pender, J. and Girmay Tesfay. 2001. "Community natural resource management: The case of woodlots in northern Ethiopia." Forthcoming Environment and Development Economics.

Berhanu Gebremedhin and Swinton, S. 2000. "Investment in Soil Conservation in Ethiopia: The role of Land Tenure Security and Public Programs." Unpublished manuscript, Department of Agricultural Economics, Michigan State University, East Lansing, USA.

Berhanu Gebremedhin, 1998. "The economics of soil conservation investments in the Tigray region of Ethiopia." Ph D Dissertation. Department of Agricultural Economics: Michigan State University, East Lansing, USA. 258 pp.

Bureau of Agriculture and Natural Resource Development (BoANRD). 1999. "Livestock census analysis results." Mekelle, Ethiopia. 230 pp.

Bureau of Agriculture and Natural Resource Development (BoANRD). 1997. "Tigray Livestock Development Action Program: Executive Summary, Volume II." Mekelle. 23 pp.

Desta Hagos. 1997 "Tigray Livestock Development Action Program." Tigray Bureau of Agriculture and Natural Resource Development: Mekelle. Mimeo.

Ehui, S, Li Pun, H., Mares, V. and Shapiro, B. 1998. "The role of livestock in food security and environmental protection." Outlook on Agriculture 27(2):81-87.

Fitsum Hagos, Pender, J. and Nega Gebreselassie. 1999. Land degradation in the highlands of Tigray and strategies for sustainable land management. Socio-economics and Policy Research Working Paper 25. ILRI (International Livestock Research Institute), Addis Ababa, Ethiopia. 80 pp. 
Gebrekidan Teklu, 1994. A need for change in policy in the traditional grazing system and ownership right on communal lands. Natural Resource and Environmental Protection (NRDEP): Mekelle, Ethiopia. mimeo. 27 pp.

ILRI (International Livestock Research Institute). 1999. ILRI 19998: Linking livestock and natural resource management. ILRI, Nairobi, Kenya.

McCarthy, N., A. Kamara and M. Kirk. 2001. The Effect of environmental Variability on Livestock and Land-Use management: The Borena Plateau, Southern Ethiopia. Environment and Production Technology Division Discussion Paper 75. Washington D.C.: iFPRI (International Food Policy Research Institute), Washington, D.C. USA.33 pp.

North, D.C. 1990. Institutions, Institutional Change and economic performance. Cambridge University Press: Cambridge, UK. 152 pp.

Oakerson, R.J. 1992. Analyzing the Commons: A Framework. In Bromely (ed), Making the Commons Work: Theory, Practice and Policy:41-62. International Center for SelfGovernance: San Fransisco.

Olson, M.. 1965. The logic of collective action. Public goods and the theory of groups. Harvard University Press: Cambridge, Massachusetts, USA. 176 pp.

Ostrom, E. 1990. Governing the commons: The evolution of institutions for collective action. Cambridge University Press: Cambridge, UK. 280 pp.

Pearce, D.W. and Turner, R.K. 1990. Economics of Natural Resources and the Environment. Harvester wheatsheaf: Hertfordshire.

Pender, J. 1999. Rural population growth, agricultural change and natural resource management in developing countries: a review of hypotheses and some evidence from Honduras. Environment and Production Technology Division Discussion Paper 48. IFPRI (International Food Policy Research Institute), Washington D.C.,USA. 59 pp.

Pender, J. and S. Scherr. 1999. Organisational development and natural resource management: Evidence from central Honduras. Environment and Production Technology Division Discussion Paper 49. IFPRI (International; Food Policy Research Institute), Washington D.C., USA. 59 pp.

Rasmusen, L.N. and R. Meinzen-Dick. 1995. Local Organisations for natural resource management: Lessons from theoretical and empirical literature. Environment and Production Technology Division Discussion Paper 11. IFPRI (International Food Policy Research Institute), Washington D.C, USA. 37 pp. 
Runge, C. F. 1981. Common Property Externalties: Isolation, Assurance, and Resource Depletion in a Traditional Grazing Context. American Journal of Agricultural Economics, 63:595606.

Runge, C. F. 1992. Common Property and Collective Action in Economic Development. World Development, 14(5): 623-635.

Swallow, B.W. and. Bromley, D.W. 1995. "Institutions, governance and incentives in common property regimes for African rangelands." Environment and Resource Economics 6:99118.

Tsigeweyni Tekleab. 1997. Tigray Soil and water conservation action program: Livestock management and forage production. Tigray Bureau of Agricultur and Natural Resource Development, Mekelle, Ethiopia. Mimeo. 37 pp.

Turner, R.K., D. Pearce and I. Bateman. 1994. Environmental economics: An introduction. Hertfordshire: Harvester Wheatsheaf, UK. 189 pp.

United Nations Economic Commission for Africa (UNECA). 1997. Livestock development in Tigray: Forage development strategy as a major entry point towards a sustainable minimum grazing system, Part I. Sustainable Development and Environmental Rehabilitation Program (SAERP): UNECA, Addis Ababa. 167 pp.

Vanderlinden, J-P. 1999. Conflicts and Cooperation over the Commons: A Conceptual and Methodological Framework for Assessing the Role of Local Institutions. In McCarthy, N. B. Swallow, M. Kirk and P. Hazzel (eds). Property Rights, Risk and livestock Development in Africa: 351-370. IFPRI (International Food Policy Research Institute), Washington D.C., USA.

Varughese, G. and Ostrom, E. 2001. 'The Contested role of heterogeneity in collective Action: Some Evidence from Community Forestry in Nepal.' World development, 29(5):747-765.

Wade, R. 1988.Village republics: Economic conditions for collective action in South India. ICS Press: Oakland, USA. 276 pp.

Wade, R.1986. "The management of common property resources: collective action as an alternative to privatisation and state regulation." Discussion paper No.54. Agricultural and Rural Development Department, The World Bank: Washington DC, USA. 36 pp.

Williamson, O.E. 1986. "The Economics of governance: framework and implications." In Langlois, R.N., (ed) Economics as a process: essays in new institutional economics: 31-65. Cambridge University Press: Cambridge, UK. 